\title{
Impact of Government Expenditure in Economic Growth of Nepal: ARDL Approach $^{1}$
}

\author{
Keshar Bahadur Kunwar
}

\begin{abstract}
Public expenditure refers to the expenditure made by public authority, i.e., central government and other local bodies to carter the demand of the people. It is for protecting the citizens and for promoting their economic and social welfare. Public expenditure is one of the instruments through which government influence economic events. The specific objective of this paper is to analyze the long run and short run relationship between public expenditure and economic growth in Nepal and to examine the Causal relationship between the public expenditure and economic growth in Nepal. The study employed quantitative techniques and econometrics methods to analyze the data. This study used time series data. Data analysis begins with the testing of the unit root of the series to confirm whether the data are stationary or not. Augmented Dicky Fuller unit root test, co-integration test is employed to check the relationship of the variables under study. One period lagged LNGE has significant and positive impact on RGDP. If 1 percent increase in GE leads to increase by 34.99 percent in RGDP at 5 percent level of significance. The coefficient of error correction term (-0.782018) is significant at one percent level. Highly significant negative sign of the error correction term strengthens the presence of long-run relationship among the variables. However, the speed of adjustment from previous year's disequilibrium in RGDP added to current year's equilibrium is only 78.20 percent. The P- value of BreuschGodfrey serial Correlation LM Test, Heteroscedasticity test: Breusch-Pagan-Godfrey and normality test is greater than 5 percent which is desirable. So, this model is free from auto correlation and heteroscedasticity. The residual is normally distributed.
\end{abstract}

Key words: public expenditure, economic growth, unit root, co-integration, ARDL

Economists are of two diverse opinions about the role of government in economic activities. According to the neo-classical economists, reducing the role of private sector by crowding out effect is important because it reduces the inflation in the economy; increase in public debt, increases the interest rate which reduces inflation in the economy as well as output. The new Keynesians present the multiplier effect in response and argue that the increase in government expenditure will increase demand and thus increase economic growth. The vision of ensuring sustainable economic development and reduction of mass poverty is enshrined, in one way or another, in the government's development strategy documents of virtually all developing economies. In this respect, economic growth, which is the annual rate of increase in a nation's real GDP, is taken as main objective for overcoming persistent poverty and offering hope for the possible improvement of society (Kakar, 2011).

\section{Literature review}

Suleiman (2009) found that the impact on public expenditures and then on deficits ascending from a structural deceleration in or from an upgrading in the growth potential. He submits that a good knowledge of the structural relation between the noncyclical section of government expenditure and possible output is crucial to obtaining a benchmark against which to assess the stance of expenditure policy and then of overall fiscal policy.

Abu and Abdullah (2010) observe that government expenditure has continued to rise due to the huge receipts from production and sales of crude oil, and the increased demand for public goods like roads, communication, power, education and health. Also, there is growing need to offer both internal and external safety for the people and the nation.

Rahman (2012) has studied on the relationship between the economic growth and expenditure in Sudan. The primary objective of the paper is to test the Wagner hypothesis in Sudan over the period of 1970-2010. The methodology used by the paper to meet the objectives is co-integration, causality and error correction model (ECM). After they have tested the Wagner hypothesis for the different countries the result was conflicting. The results for the Sudan indicate that the data for the periods support of the Wagner hypothesis.

\footnotetext{
${ }^{1}$ Cite this article as: Kunwar, K. B. (2019). Contemporary Research: An Interdisciplinary Academic Journal, vol. 3 (1) Keshar Bahadur Kunwar, Associate Professor, Tikapur Multiple Campus, Far Western University, Nepal Email: keshar497@gmail.com

Peer reviewed under the authority of CRAIAJ, academic journal of Ghodaghodi Multiple Campus, Kailali, Nepal. (C) 2019 Contemporary Research: An Interdisciplinary Academic Journal
} 
Alshahrani and Alsadiq (2014) an IMF working paper examined the relationship between the economic growth and government spending in Saudi Arabia. The main objective of the paper is to find out the effect of the total as well as sectoral government expenditure in total production of the country and hence in the economic growth of the country. It used ADF technique to check whether the data set is stationary or not. After this it employed Johanson co-integration technique to see the long run relationship and used VECM to check the short run relationship between the variables. It employed annual data over the period 1969-2010. The papers findings that private domestic and public investments, as well as health care expenditure, stimulate growth in the long-run, openness to trade and spending in the housing sector can also boost short-run production.

Gyanwaly (2014) has examined the relationship between the financial development and economic growth in Nepal. The main objectives of the research are to find out the relationship between the financial development and economic growth in Nepal. It has used the data for the period of 1975 to 2014. It has developed the financial index by taking the weighted average of the different indicators of the financial development. After this it has used ADF test to check the stationary of the variables and used Johanson co-integration technique and error correction model (ECM) to check the long run relationship between the variables. The findings of the research are financial development, real stock of capital, real per capita capital, labor force, real export and government expenditure have significantly positive relationship with economic growth while inflation and trade openness have significantly negative relationship with economic growth.

Ogbokor (2015) has studied about the dynamic relationship between the government expenditure and economic growth in the Namibia. The objectives of the research are to find out the relationship between the government expenditure and economic growth and to check the direction of causality between them. The annual time- series macroeconomics secondary data-set from 1990 to 2013 were used. Paper used the two- step Engle- Granger approach to check the causality between the variables and it uses the co-integration technique to check the long run relationship between them. The study found cointegration relationships among public expenditure and economic growth and there is unidirectional causality between them. Additional, the paper found that government spending and expenditures on education and health are all weak forecasters of economic growth.

\section{Objectives of the study}

The general objective of this paper is to analyze the relationship between the Public expenditure and economic growth in Nepal.

- To analyze the long run and short run relationship between public expenditure and economic growth in Nepal.

- To examine the Causal relationship between the public expenditure and economic growth in Nepal.

\section{Hypothesis of the study}

The hypothesis of the study is as below:

- Null Hypothesis $\left(H_{0}\right)$ : There is no significant relationship between the public expenditure and economic growth.

- Alternative Hypothesis $\left(H_{1}\right)$ : There is significant relationship between the public expenditure and economic growth.

\section{Research methodology}

This study is based on secondary data. For the study, dependent variable is economic growth proxy variable is RGDP whereas government expenditure, import, export; foreign aid, total investment and remittance are independent variables. This study is based on secondary sources of data of Nepal for the period of 1974/75 to 2017/18 leading to the total of forty-four observations.

\section{Techniques of data analysis}

The study employed quantitative techniques and econometrics methods to analyze the data. This study used time series data. Data analysis begins with the testing of the unit root of the series to confirm whether the data are stationary or not. Augmented Dicky Fuller unit root test, co-integration test is employed to check the relationship of the variables under study. ARDL estimation is employed as per the result of the co-integration test. Likewise, post estimation test like serial correlation test, normality test, heteroscedasticity test, granger causality test and cumulative sum of recursive residuals (CUSUM), cumulative sum of squares of recursive residuals (CUSUMQ) have been employed to test the stability of the model.

\section{The model specification}

This study has applied some macro-economic development indicators such as RGDP, GE, REM, FA, IMP, EXP and TI. However, this study has been improved one in comparison to other earlier studies on the basis of using forty-four years from 
1974/75to 2017/18or on the basis of improved models have been used and it captures the link between GE and major macroeconomic variables i.e. RGDP, GE, REM, FA, IMP, EXP and TI.

The general model is

$\mathrm{RGDP}=\mathrm{f}(\mathrm{GE}, \mathrm{REM}, \mathrm{FA}, \mathrm{IMP}, \mathrm{EXP}, \mathrm{TI})$ ..(Model 1)

Model 1 can be rearranged in natural logarithm form

$\operatorname{Ln} \operatorname{RGDP}_{t}=\beta_{0}+\beta_{1} \operatorname{Ln}\left(G_{t}\right)+\beta_{2} \operatorname{Ln}\left(\operatorname{REM}_{t}\right)+\beta_{3} \operatorname{Ln}\left(\mathrm{FA}_{t}\right)+\beta_{4} \operatorname{Ln}\left(\mathrm{IMP}_{\mathrm{t}}\right)+\beta_{5} \operatorname{Ln}\left(\mathrm{EXP}_{\mathrm{t}}\right)+\beta_{6} \operatorname{Ln}\left(\mathrm{TI}_{\mathrm{t}}\right)+\mu_{\mathrm{t}}$ .. (1.1)

Based on our model, ARDL bound testing will be as:

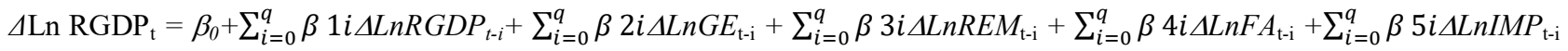



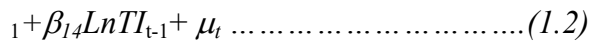

Where $\Delta$ is the first difference operator, $\mathrm{q}$ is the optimum lag length, $\beta_{1}$--- $\beta_{7}$ are short run dynamics of the model and $\beta_{8}$--$\beta_{14}$ are long run elasticity. $\mu_{\mathrm{t}}$ is the error term. We conducted bound test based on the above equation. As per the result of the bound test, if the value of calculate F statistics, is greater than the upper bound I (1), the null hypothesis should be rejected. If the calculated value of $\mathrm{F}$ statistics is greater than the upper bound, there exists co-integration and the study further proceeds for error correction version of the above equation. If $\mathrm{F}$ statistics is less than the lower bound or inconclusive value comes between the lower bound I(0) and upper bound I (1) in this case we run ARD short run which is based on OLS method.

$\Delta \operatorname{Ln~RGDP}_{\mathrm{t}}=\beta_{0}+\sum_{i=0}^{q} \beta 1 i \Delta L n R G D P_{t-i}+\sum_{i=0}^{q} \beta 2 i \Delta L n G E_{\mathrm{t}-\mathrm{i}}+\sum_{i=0}^{q} \beta 3 i \Delta L n R E M_{\mathrm{t}-\mathrm{i}}+\sum_{i=0}^{q} \beta 4 i \Delta \operatorname{LnF} A_{\mathrm{t}-\mathrm{i}}+\sum_{i=0}^{q} \beta 5 i \Delta L n I M P_{\mathrm{t}-\mathrm{i}}$ $+\sum_{i=0}^{q} \beta 6 i \operatorname{LnEXP} P_{\mathrm{t}-\mathrm{i}}+\sum_{i=0}^{q} \beta 7 i \operatorname{LnTI} I_{\mathrm{t}-\mathrm{i} 1}+\lambda E C T_{t-i}+\mu_{t} \ldots \ldots \ldots \ldots(1.3)$

Where $\mathrm{q}_{1}$--- $\mathrm{q}_{7}$ are optimal lag length and $\lambda$ is the speed of adjustment parameter. ECT represents the error correction term derived from long run relationship from the above equation.

\section{Result analysis}

\section{Unit root test}

Using time series data in a research study is crucial. Time series data normally are on non-stationary and non-stationary data are unpredictable and cannot be modeled or forecasted. The result that is obtained from non-stationary time series data may be spurious and less reliable. So, result obtained from the study should be valid and consistent. Thus, if the data are nonstationary, then they should be transferred into stationary data.

This study employs Augmented Dickey-Fuller (ADF) unit root test to check the stationary. The result obtained from the formal unit root test is summarized as:

Table: 1.1Augmented Dickey Fuller Test

\begin{tabular}{|l|l|l|l|}
\hline Variables & Level constant and trend & $\begin{array}{l}\text { First difference } \\
\text { constant and trend }\end{array}$ & $\begin{array}{l}\text { Order of } \\
\text { integration }\end{array}$ \\
\hline LnRGDP & $-2.025353(0.5705)$ & $-6.663060(0.0000)$ & $I(1)$ \\
\hline LnGE & $-2.135894(0.5118)$ & $-5.354948(0.0004)$ & $I(1)$ \\
\hline LnREM & $-2.113799(0.5237)$ & $-7.602489(0.0000)$ & $I(1)$ \\
\hline LnFA & $-3.810386(0.0255)$ & $-6.780302(0.0000)$ & $I(0), I(1)$ \\
\hline LnIMP & $-2.052282(0.5568)$ & $-6.782562(0.0000)$ & $I(1)$ \\
\hline LnEXP & $-0.720756(0.9649)$ & $-5.328052(0.0005)$ & $I(1)$ \\
\hline LnTI & $-1.435647(0.8351)$ & $-3.626550(0.0397)$ & $I(1)$ \\
\hline
\end{tabular}

Source: Researcher's calculation using EViews 10

By observing the table 1.1 it can be seen that the variable under study, namely; Ln FA is stationary at level as per the ADF test. While others are not stationary. When we convert all the data in the first difference, all the variables are become stationary. It means the data are of mixed type of I (0) and I (I). When the data are of mixed order of integration, the study cannot proceed for Johansen Co-integration test. So, it is proceeded for Auto-regressive Distributive Lag (ARDL) model for further processing.

Lag length selection

When the time series data are used to economic modeling, lag selection is very crucial and quite sensitive. Thus, an appropriate criterion for the selection of lag is very important. There are different criteria available for the selection of the model but Akaike Information Criterion (AIC) and Schwaz information criterion (SC) are most popular methods in time series 
Kunwar, K. B. (2019), CRAIAJ, vol. 3 (1): 33-40

data analysis. The result obtained from the lag selection criteria is 3 optimum lag for this model which is presented in the table 1.2 below.

Table 1.2 : Optimum lag selection on the basis of AIC criterion

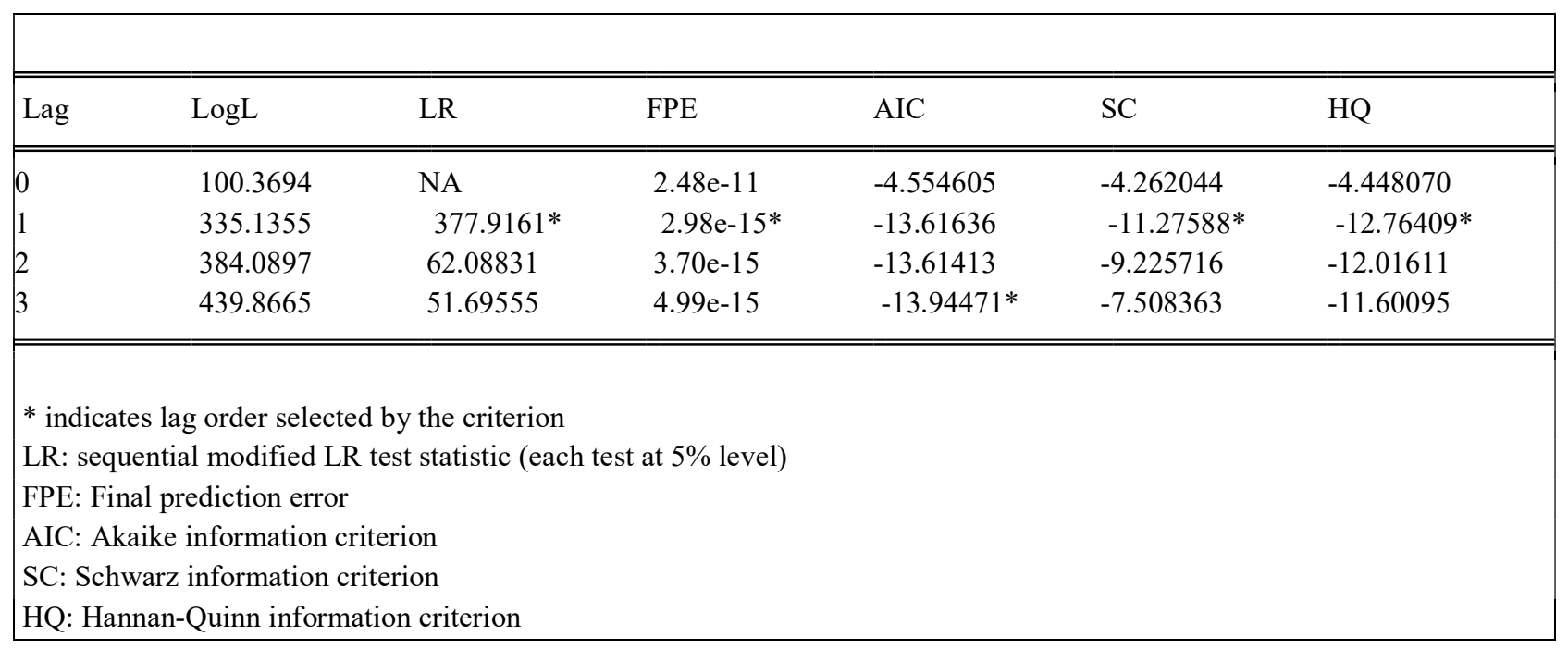

Source: Researcher's calculation using EViews 10

\section{Bound testing}

The data used in the study are of mixed order and they became stationary after first differentiate. When the data are of I (0) and I (1), in that situation, the study can only apply ARDL bound testing model. The existence of co-integration among the variables under study can be confirmed from the bound testing. The decision criteria proposed by Pesaran et al. (2001) is as: (See in Appendix II)

i) If the calculated value of $F$ statistics is greater than the upper bound of the critical values, it can be confirmed that there exists a co-integration.

ii) If the calculated value of F statistics is less than the lower bound of the critical values, then the study concluded that there is no co-integration among the variables.

iii) If the calculated value of the F statistics lies between the upper and lower bound of the critical values than it can be concluded that there is inconclusive co-integration or it is not confirmed whether there is co-integration or not. Table:1.3 Bound Test

\begin{tabular}{|lllll|}
\hline F-Bounds Test & & \multicolumn{2}{l|}{ Null Hypothesis: No levels relationship } \\
\hline \hline Test Statistic & Value & Signif. & $\mathrm{I}(0)$ & $\mathrm{I}(1)$ \\
\hline \hline F-statistic & 10.63425 & $10 \%$ & 1.99 & 2.94 \\
K & 6 & $5 \%$ & 2.27 & 3.28 \\
& & $2.5 \%$ & 2.55 & 3.61 \\
& & $1 \%$ & 2.88 & 3.99 \\
\hline \hline
\end{tabular}

Source: Researcher's calculation using EViews 10

In above table F- statistic 10.63425 is greater than upper bound I (1) so we can reject null hypothesis and accept there exist long run relationship. So here we can run long run, short run and ECM through ARDL.

ARDL estimation

The study employed ARDL estimation to examine the short-run and long-run association ship among the variables. First, the ARDL bound test is conducted and the result obtained from the test is presented as:

Table:1.4 Long-Run Coefficients of ARDL(1, 2, 2, 0, 0, 0, 1) Model Dependent Variable D(LNRGDP)

\begin{tabular}{|lllll|}
\hline \hline Variable & Coefficient & Std. Error & t-Statistic & Prob. \\
\hline
\end{tabular}


Kunwar, K. B. (2019), CRAIAJ, vol. 3 (1): 33-40

\begin{tabular}{|c|c|c|c|c|}
\hline $\mathrm{C}$ & 3.724630 & 0.659096 & 5.651120 & 0.0000 \\
\hline $\operatorname{LNRGDP}(-1)^{*}$ & -0.782018 & 0.122375 & -6.390320 & 0.0000 \\
\hline $\operatorname{LNGE}(-1)$ & 0.349962 & 0.098759 & 3.543584 & 0.0014 \\
\hline LNREM(-1) & 0.040955 & 0.017511 & 2.338827 & 0.0264 \\
\hline LNFA $^{* *}$ & -0.142186 & 0.055344 & -2.569142 & 0.0156 \\
\hline LNIMP** & 0.086840 & 0.072736 & 1.193908 & 0.2422 \\
\hline LNEXP** & 0.098216 & 0.023513 & 4.177114 & 0.0002 \\
\hline LNTI(-1) & 0.073409 & 0.116279 & 0.631320 & 0.5328 \\
\hline D(LNGE) & 0.271851 & 0.116034 & 2.342859 & 0.0262 \\
\hline $\mathrm{D}(\mathrm{LNGE}(-1))$ & -0.193156 & 0.083172 & -2.322350 & 0.0274 \\
\hline D(LNREM) & -0.010519 & 0.029081 & -0.361720 & 0.7202 \\
\hline D(LNREM(-1)) & -0.067822 & 0.025825 & -2.626212 & 0.0136 \\
\hline $\mathrm{D}(\mathrm{LNTI})$ & -0.194669 & 0.112633 & -1.728353 & 0.0946 \\
\hline
\end{tabular}

Source: Researcher's calculation using EViews 10

Table 1.4 reveals that one period lagged RGDP is the most significant factor of RGDP value added in Nepal. The coefficient (0.782018 ) of LNRGDP (-1) shows that one percent increase in lagged RGDP leads to over 78.20 percent decrease in RGDP value in the long-run at 1 percent level of significance. One period lagged LNGE has significant and positive impact on RGDP. If 1 percent increase in GE leads to increase by 34.99 percent in RGDP at 5 percent level of significance. LNFA has positive and significant impact on RGDP in the long run. LNIMP has positive but insignificant impact on RGDP. As the same way LNEXP has positive and significant impact on RGDP in Nepal in the long run.

Table $: 1.5$

Error Correction Representation of the Selected ARDL(1, 2, 2, 0, 0, 0, 1) Model Dependent Variable D(LNRGDP)

\begin{tabular}{|lll|lc|}
\hline \hline Variable & Coefficient & Std. Error & t-Statistic & Prob. \\
\hline \hline D(LNGE) & 0.271851 & 0.072911 & 3.728553 & 0.0008 \\
D(LNGE(-1)) & -0.193156 & 0.061380 & -3.146890 & 0.0038 \\
D(LNREM) & -0.010519 & 0.019582 & -0.537206 & 0.5952 \\
D(LNREM(-1)) & -0.067822 & 0.019663 & -3.449257 & 0.0017 \\
D(LNTI) & -0.194669 & 0.070153 & -2.774936 & 0.0096 \\
ECT $(-1) *$ & -0.782018 & 0.076097 & -10.27663 & 0.0000 \\
\hline \hline R-squared & 0.691898 & Mean dependent var & 0.045679 \\
Adjusted R-squared & 0.649106 & S.D. dependent var & 0.049516 \\
S.E. of regression & 0.029331 & Akaike info criterion & -4.088751 \\
Sum squared resid & 0.030972 & Schwarz criterion & -3.840512 \\
Log likelihood & 91.86376 & Hannan-Quinn criter. & -3.997761 \\
Durbin-Watson stat & 1.952030 & & & \\
\hline \hline * p-value incompatible with t-Bounds distribution. & & \\
\hline
\end{tabular}

Source: Researcher's calculation using EViews 10

Table 1.5 contains the results of error correction representation of the selected ARDL model. Coefficients of the variables with first difference show the short-run elasticity. Result shows that variable LNGE has positive and significant relationship with the dependent variable LNRGDP at a 5 percent significance level. It means 1 percent increase in GE leads 27.18 percent increase in RGDP. The coefficient of error correction term (-0.782018) is significant at one percent level. Highly significant negative sign of the error correction term strengthens the presence of long-run relationship among the variables. However, the speed of adjustment from previous year's disequilibrium in RGDP added to current year's equilibrium is only 78.20 percent.

Diagnostic tests 
Conducting numerous diagnostic tests is a vital step in time series modeling. Diagnostic testing on data series thus offers information regarding how these data might be modeled. When a model is assessed, diagnostic tests can be applied to appraise model residuals, which also help as tests of model competence.

Table: 1.6 Diagnostic Tests

\begin{tabular}{|l|l|l|l|}
\hline Test & $\begin{array}{l}\text { F-Statistics } \\
\text { /Jarque-bera }\end{array}$ & Obs*R-squared & P- Value \\
\hline Breusch-Godfrey Serial Correlation LM Test: & 0.091826 & 0.283751 & 0.8677 \\
\hline Heteroscedasticity Test: Breusch-Pagan-Godfrey & 1.963003 & 18.82474 & 0.0928 \\
\hline Normality & 3.836546 & ----- & 0.146860 \\
\hline
\end{tabular}

The P- value of Breusch-Godfrey serial Correlation LM Test, Heteroscedasticity test: Breusch-Pagan-Godfrey and normality test is greater than 5 percent which is desirable. So, this model is free from autocorrelation and heteroscedasticity. The residual is normally distributed.

\section{The stability test}

The CUSUM test is one of the most commonly used techniques to perceive change points. It started in quality control and moved to time series analysis since time series data suffer from changes due to the change of public policies and serious social measures. It is easy to know and execute in real usage, and can be applied for both testing and estimating the positions of changes.

The study employs Cumulative sum of recursive residuals (CUSUM) and cumulative sum of squares of recursive residuals (CUSUMQ) test to check the stability of the model. The result of the CUSUM and CUSUMQ is presented by the following figures respectively.

Figure: 1.1 CUSUM Test and CUSUM of Square Test

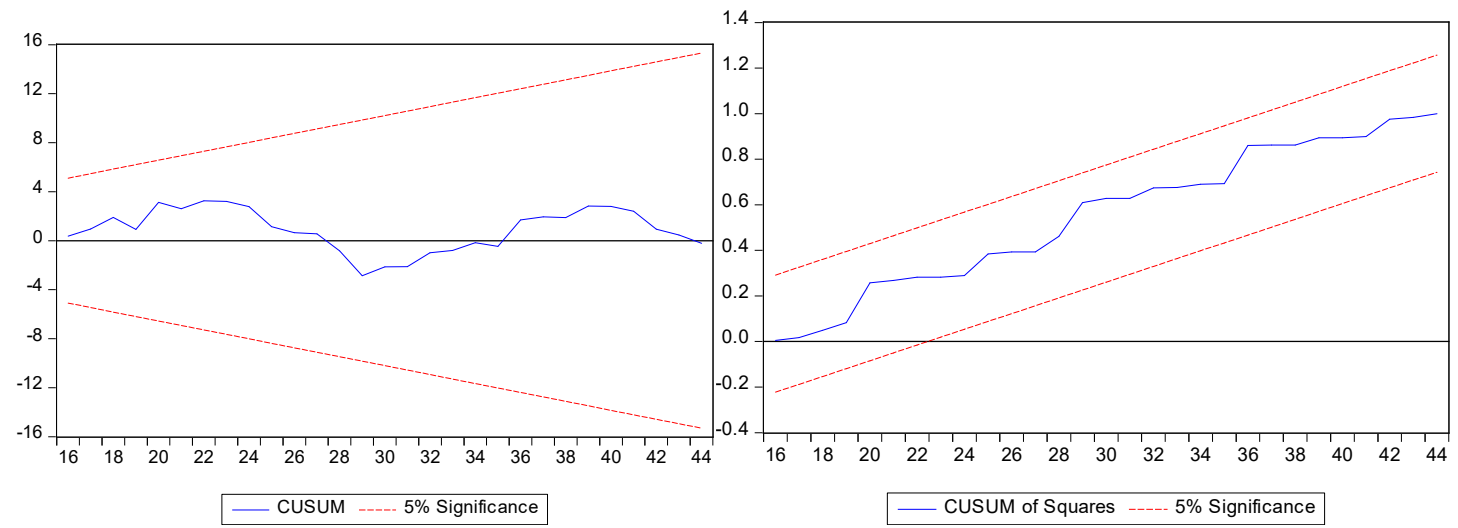

The study conducted the CUSUM and CUSUM OF SQUARE test to test the stability of the model. If the plot of CUSUM lies within the 5 percent critical bound, then we cannot reject the null hypothesis of the stability of the parameters. As it is observed in the figure 1.1, it can be seen that the lines are between the significant of 5 percent. It implies that this model is robust and stable as the both lines long run and short run coefficients are acceptable over the study period 1994/75 to 2017/18. The diagnostic tests confirm that the models have the desired econometric properties. we conclude that the models are structurally stable.

\section{Causality test}

To test the causal relationship among the variables under study, the study employed pairwise Granger-Causality test. As it is confirmed from the cointegration test that there is cointegration among the variables under study. The concern is whether there is causal relationship among the variables. The study further, conducted the pairwise Granger-causality test to check if there is a causal relationship between value added tax and economic growth in Nepal and the result obtained is presented as

Table:1.7 Summary of Granger Causality Test

\begin{tabular}{|l|l|}
\hline Model 1: RGDP = f ( GE, FA, REM, IMP, EXP, TI) \\
\hline LNGE LNRGDP & \multicolumn{2}{|l|}{} \\
\hline LNRGDPLNEXP & Unidirectional Granger Causality \\
\hline
\end{tabular}




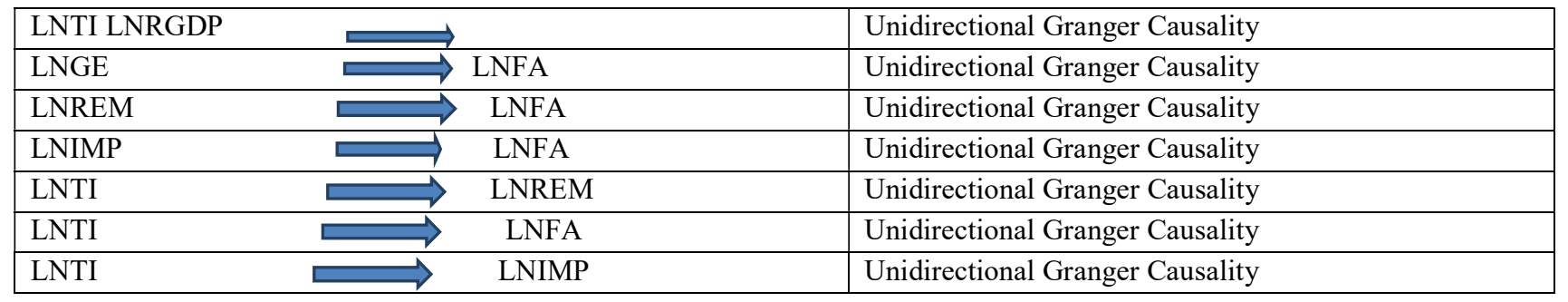

The pairwise Granger causality test carried out on which is depicted in table 1.7 Many variables are statistically significance at 5 percent significance level leading to the rejection of the null hypothesis they have unidirectional causality. The summary of pair wise Granger causality has been shown in above table 1.7.

\section{Conclusion}

It is concluded that one period lagged RGDP is the most significant factor of RGDP value added in Nepal. The coefficient (0.782018) of LNRGDP (-1) shows that one percent increase in lagged RGDP leads to over 78.20 percent decrease in RGDP value in the long-run at 1 percent level of significance. One period lagged LNGE has significant and positive impact on RGDP. If 1 percent increase in GE leads to increase by 34.99 percent in RGDP at 5 percent level of significance. The coefficient of error correction term (-0.782018) is significant at one percent level. Highly significant negative sign of the error correction term strengthens the presence of long-run relationship among the variables. However, the speed of adjustment from previous year's disequilibrium in RGDP added to current year's equilibrium is only 78.20 percent. The P- value of BreuschGodfrey serial Correlation LM Test, Heteroscedasticity test: Breusch-Pagan-Godfrey and normality test is greater than 5 percent which is desirable. So, this model is free from autocorrelation and heteroscedasticity. The residual is normally distributed. It implies that this model is robust and stable as the both lines long run and short run coefficients are acceptable over the study period $1994 / 75$ to $2017 / 18$. The diagnostic tests confirm that the models have the desired econometric properties. It is concluded that the models are structurally stable.

\section{Reference}

Abu, N. \& Abdullahi, U. (2010). Government expenditure and economic growth in Nigeria, 1970-2008: A disaggregated analysis. Business and Economics Journal, Vol 4: 2-4.

Alshahrani, S., \& Alsadiq, A. J. (2014). Economic growth and government spending in Saudi Arabia: An Emperical investigation. IMF Working Paper. Retrieved from https://www.imf.org/external/pubs/ft/wp/2014/wp1403.pdf

Dickey. D. A. \& W. A. Fuller (1979). Distribution of estimators of autoregressive time series with a unit root. Journal of the American Statistical Association, 74, 427-31.

Engle, R. and Granger, C. W.J. (1987). Cointegration and error correction: Representation, estimation and testing, Econometrica, 35, 251276

Gujarati, D.N.,Porter, D.C., Gunasekar, S. ( 2012). Basic econometrics, fifth edition. McGraw Hill Education (India) Pvt.Ltd, New Delhi. Gyanwaly, R. P. (2014). Financial development and economics growth in Nepal. Nepalese Journal of Economic Studies, 1(1), $14-26$.

Kakar, K. (2011). Impact of fiscal variables on economic development of Pakistan. Romanian Journal of Fiscal Policy, 2, 1-10 Akpan, N. (2005). Government

Ogbokor, C. A. (2015). Exploring co-integration and causality relationships between government expenditure and economic performance in Namibia. Developing Country $\quad$ Studies, $\quad 5(9)$. $\quad$ Retrieved from http://ir.nust.na/bitstream/handle/10628/523/Ogbokor.\%20Exploring\%20Cointegration\%20and\%20Causality\%20Relationshi ps\%20between.pdf?sequence $=1 \&$ isA llowed $=y$

Pesaran, H. M., Y. Shin \& R. J. Smith (2001), Bounds testing approaches to the analysis of long-run relationships. Journal of Applied Econometrics, Volume 16, 289-326.

Pesaran, H. M. and Y. Shin (1999), An autoregressive distributed lag modeling approach to cointegration analysis. In Strom, S. (ed.), Econometrics and economic theory in the 20th Century. The Ragnar Frisch centennial symposium. Cambridge: Cambridge University Press.

Pesaran, H. M., Y. Shin and R. J. Smith (2001). Bounds testing approaches to the analysis of long-run relationships. Journal of Applied Econometrics, Volume 16, pp. 289- 
Kunwar, K. B. (2019), CRAIAJ, vol. 3 (1): 33-40

Rahman, M. (2012). The relationship between economic growth and government expenditure: Evidence from Sudan. International Business Research, 5(8). Retrieved from file://C:/Users/carol/AppData/Local/Temp/18466-61378-1-PB-2.pdf

Suleiman, A. \& S. Aruwa (2009): Public finances and economic growth in Nigeria: Fiscal policy implications in crises era". www.academia.com. 